\title{
Marketing of cilembu sweet potato seeds in the cybernetics era through the content of
}

\section{Dongeng Hui Cilembu: a study of ethnostorytelling at Cilembu Village, Sumedang, West Java, Indonesia}

\author{
Susanti Agustina ${ }^{1 *}$,Wina Erwina ${ }^{2}$ \\ ${ }^{1}$ Library and Information Science Study Program, Department of Curriculum and Educational Technology, Faculty of Science \\ Education, Indonesia University of Education, Indonesia. \\ ${ }^{2}$ Department of Information Science and Library, Faculty of Communication, Padjadjaran University, Indonesia \\ *Corresponding author: susanti@upi.edu
}

\section{ABSTRACT}

This study aims to describe the role of folktale as indigenous knowledge which is communicated from generation to generation from the older to the younger people in developing Cilembu sweet potato cultivation system based on local wisdom. The spoken culture of Dongeng Hui Cilembu (Tale of Cilembu Sweet Potato) has made the locals believe that the cultivation of Cilembu sweet potato can only be performed in Cilembu village, thus if grown in other regions, it will not be sweet. This belief generates problems when sweet potato export demand increases while the fields are limited, harvest acceleration is hampered and the price of crop is low because the management is still conventional. On the one hand, Dongeng Hui Cilembu can maintain local wisdom. However, on the other hand, decreased productivity causes financial problems for the farmers. The subject of the study is the young people of Cilembu village and the object of the study is Dongeng Hui Cilembu. This study used the qualitative method with case study approach. Data were collected through interview, observation and document study. Dongeng Hui Cilembu which is believed to be a myth, in fact can be an effective marketing content in the cybernetics era. The marketing of Cilembu sweet potato seeds that is wrapped with ethnostorytelling is an interesting part from the study's findings. Dongeng Hui Cilembu as a folktale can boost the sales of Cilembu sweet potato seeds and increase the farmers' revenue (microfinancial) that affects not only the preservation of local wisdom but also sustainability of economic development.

Keywords: Cilembu sweet potato, cybernetics,
economic literacy, ethnostorytelling, folktale

\section{INTRODUCTION}

In the preliminary stages of the project, formulation of the problem came from a brief conversation in a traditional shop Pajungjugan in a natural tourism attraction in Cilembu Village, Pamulihan District. The researchers had a conversation with a young mother with one child who was then serving us snacks as we were resting. The researchers inquired about the central location of the cultivation of Cilembu sweet potato. In addition, the researchers also inquired why the Cilembu sweet potato has a taste as sweet as honey. The young mother told us that according to her parents the Cilembu sweet potato tastes sweet like honey because it is washed with water from Cilembu springs. When the potato is grown elsewhere, it would not taste as good as the one grown in Cilembu village. "My father said, water from Cilembu village makes the harvested sweet potato release a sweet flavor like honey when baked. If it is not washed with water from here, the taste will not be sweet", she said. "But I consider it a myth," she remarked.

After the conversation, the researcher was interested to dig deeper into the belief of the Cilembu village community on the commodity that became its trademark, the sweet potato: about the relevance of the water used 
for washing with the sweet taste of the potato, the linkages between past stories and beliefs that is formed in the present, how the local community believes in a myth, and a story of ancestors, in a sustainable economic system as a livelihood. All of it was interesting to be studied further. The uniqueness of the story that is passed down from generation to generation needs to be investigated as an intangible cultural heritage.

\section{METHOD}

The ethnosystem approach has been used successfully in several socioeconomic and cultural research projects and it is continually being adapted and improved, ( $c f$. Slikkerveer, 2005, 2006). Furthermore, ethnostorytelling is composed of two wodes, namely ethno which menas "race, culture," from the Greek ethnos "people, caste, class, ethnicity, nation; a number of people who are used to living together". It is used to form compounds in the modern social sciences. While storytelling refers to the folktales, story, narrative, myth, legend, both oral and written. Both words combined means storytelling culture, by examining the relationship between the tale as a speech language and the culture that guards it. It is a combination of Ethnology and storytelling. The study refers to the life of the community where a story or a folktale develops. All the characteristics of speech language, folktales, stories, legends, myths distinguished ne community from another. These characteristics form the aspects of culture and society.

In ethnostorytelling, challenges occur when collecting diverse versions of the presented story, although they lead to the same purpose. The difference between the stories presented orally and in writing facilitates the building of meaning of information between researchers, participants, and key informants. Stories can be a tool to deliver information from the narrative. Stories can help researchers and others to explore and interpret the world and place where the local people live. Stories are considered as a generative tool to co-design that is capable of recording the self-expression (Saunders, 2000). Thus, stories are useful to draw interest in someone or something. Stories make something unique.

In the cyber era, information can be obtained in a comprehensive system. In order to obtain something that is needed, individuals will use the Internet in search for a solution. The Internet has been the most intensive information system in use today. The researchers then searched the trail of Cilembu sweet potato story on the Internet. This is to observe the response to the story of
Cilembu sweet potato in the virtual world. Apparently, online study results show the unique facts about Cilembu sweet potato stories, "Dongeng Hui Cilembu" (Tale of Cilembu Sweet Potato) in generation 2.0, where they build a community of Cilembu sweet potato business by using local wisdom in the form of a story in marketing the Cilembu sweet potatoes either raw or diverse derivative products. Due to this the sales of sweet potato in the virtual world become more creative. How is the role of stories as local knowledge of Cilembu village community in empowering and contributing to economic development sustainability?

This study began by building a synthesis of the personal stories of participants/key informants to be a platform for further discussion and analysis of marketing of Cilembu potato seeds in the era of cybernetics through DHC (Dongeng Hui Cilembu). This paper's discussion is based on case studies involving key informants (KI 1 and KI 2). KI 1 a young high school graduate in Cilembu village, Sumedang, who has successfully developed a business of Cilembu sweet potato seeds to foreign countries through the company he started with his family, named CV PUCIMA (Puseur Ubi Cilembu Madu/Center of Cilembu Honey Sweet Potato). The online marketing that he implemented is supported by reading, mastery of information technology, blog writing, and the love for local wisdom. KI 2 is his father who is also a care taker of PUCIMA and successfully achieved the certification of Geographical Indications (patents) in 2013.

\section{RESULTS}

\section{The Role of Story as Indigenous Knowledge to} Cultivation of Cilembu Sweet Potato

In the online search about DHC, the researchers discover a unique writing that creatively wraps the story of Cilembu sweet potato. The story hypnotizes the readers, which make them unaware that the presentation of the story is aimed for marketing, promotion, and advertising. Additionally, through a story, a person can easily absorb knowledge and be affected. The resulting influence of a story can be motivation, inspiration, fantasy, desire, even a feeling of rejection, resistance, or "closing" (purchase) in the context of commerce. KI 1, in his blog, even presents a story with contradictory title.

If the conventional marketing direct sellers offer wares, then in the second generation cybernetic era, everything 
has changed. Individuals may naively use elements perceived as "negative" impact but "positive". Conventional marketing generally offer promises, positive things in the beginning. While in cybernetics, this era of marketing provides knowledge of the mission. Consumers gain knowledge of the products and services offered based on those values. This is based on the context he wants to appear as a "trigger" so that people are interested in buying a product.

\section{Cybernetics-Based Information Pattern}

Cybernetics can help in understanding how knowledge itself is generated. Cybernetics as a controlled system has a predetermined purpose. Meanwhile, cybernetics as an autonomous system leads to systems that define their own purpose (Becker, et al, 2006). Local stories combined with scientific knowledge are aimed to wrap marketing that has a value. The following is a pattern that can be learned from the container (blog), content, context that belongs to $\mathrm{KI}$ in marketing Cilembu sweet potato seeds.

\section{Table 1. Cybernetics-Based Information Pattern (June, 2013; 01:38 WIB)}

Based on Table 1, it can be concluded that the pattern of information contained in KI's blog (as a container) reveals more scientific knowledge facts (K), i.e. $44 \%$ of the total writing content is on the context of marketing of Cilembu sweet potato seeds. Then, the marketing mission (M) has $36 \%$ of the total writing content on the context of marketing of Cilembu sweet potato seeds. While the local story itself is $16 \%$ of the total writing content on the context of marketing of Cilembu sweet potato seeds.

The writing pattern in the first paragraph, $\mathrm{P}=\mathrm{S} 1+(\mathrm{K} 1$ $+\mathrm{K} 2)+(\mathrm{M} 1+\mathrm{M} 2)$, means that the writing of information begins with a prologue $(\mathrm{P})$ in the form of a quote of case examples that becomes the main idea of the information that will be presented. It ends with the question of why. This question at the same time opens the chance to deliver more about the context.

("Mr. Martono, in Salatiga, Central Java, had tried to plant Cilembu sweet potato using seeds that were taken directly from Cilembu village, Sumedang District, West Java. However, in Salatiga, the potato does not taste sweet. Why?")
Subsequently, in the first paragraph, KI began with a story/narrative of DHC in the concluded version, it was no longer telling the original history. KI assumed that customers already knew the story of DHC, so he did not need to tell it in detail. Interestingly, KI actually makes a "trigger" in the title of narrative in his blog. The sentence also reminds the readers on the original DHC local story. ("It began when the Prince of Sumedang disguised as an old man visited the entire territory. One day, the prince visited Cilembu village. He met villagers who were harvesting sweet potatoes. On that occasion, the prince was served a dish of sweet potatoes by the local people. The prince gladly enjoyed the dish. The disguising prince of Sumedang was happy and grateful for the hospitality and sincerity of the people. Hence the prince said: "Someday, these sweet and delicious potatoes would be the potatoes that lift and give welfare to the people of this village, and the potatoes cannot be grown elsewhere". The old man hurried away leaving the villagers of Cilembu. Afterward, the people realized that the old man was the Prince of Sumedang.")

That is the local version of the story which is passed down from generation to generation until the story develops and is believed increasingly by the local people. Meanwhile, the informaton Age is characterized by information overload and difficulty experienced in making sense of the data (Doyle \& Tharme, 2011).

"Prior to 1980, the sweet potato had not been a leading commodity of Cilembu village farmers. Sweet potatoes are planted only after harvesting rice. The sweet potato was not traded like it is today. At that time, sweet potato was only an alternative if the staple food harvest failed. It was only in the 80s, the kuwu (village head) named Daud, a retired military who popularized the sweet potato as a superior product that has now lifted the economy of local communities."

"The prince was offered sweet potatoes, like these (pointing to a plate of sweet potatoes on the table). The prince asked "this sweet potato, where are they from? "Of course, they are from here", they replied. "All of them are sweet," he said. I don't know the exact story. According to the stories from my parents, that was the beginning. There were research conducted by IPB and UNPAD as experts in the field. It turns out that the sweetness of Cilembu sweet potato is influenced by elements of water, soil and air. All these elements exist in the Cilembu village thus supporting the produce of sweet potato plants which have different qualities than the others ". 
"As I recall, in 1995 I had joined a farmer's group. Its chairman was Taryana. Alhamdulillah he was dispatched to do internship in Japan. In 1995, Cilembu (sweet potato) was not widely known yet. It reached only until the base, still around Cilembu. Passed the river, river, river, this is Cilembu. Cilembu village and over there the base, over there I don't know. The taste changes, even in the same village. I don't know why. Like when I followed father harvesting the potato in this block, Cilembu. A different river, "Well, that would taste differently". A different taste. The best Cilembu sweet potato is named nirkum. Nirkum is said to be the name given by our ancestors. 'Nir' the language aimed at the Dutch officers 'menir' (meneer-Dutch). While 'kum' originated from Arabic which means all or everything which refer to the general public. Thus, it is not awkward when the authorities consumed Cilembu sweet potatoes, and it is not a foreign food when eaten by the locals. After naming it nirkum, the sweet potato still exists").

As an oral tradition, DHC is a local story which brings belief to the villagers of Cilembu, Pamulihan District. However, the belief of the local story is increasingly shifting. The demand for sweet potato to foreign countries increases up to 40 tons a week, if the sweet potato is available, while availability of land is increasingly limited. To meet market demand, the system which was believed for a long time was adjusted over time. Cilembu potato seeds became a trade and began to be planted in other regions. PUCIMA captured the marketing opportunities of Cilembu sweet potato by proposing the Geographical Indications (patents) of KEMENHUKHAM of Indonesia. By legally possessing this certificate, the seeds' taste and quality are assured. Meanwhile legality has been gained by 4 districts, Pamulihan Cilembu, Rancakalong, Tanjungsari, and Sukasari. However, even when it is equaled, the sweet potato's taste of the 4 districts in not the same, although the quality of the potato is equal.

Currently, the market demand for Cilembu sweet potato is rapidly increasing. So in addition of marketing, they also need to increase production. Because, in a recent post-export, the market demand was 1.000 tons a month from all exporters, including from KI 2's brother, Taryana, to Southeast Asia, Asia, and even Europe.

Despite the fact, in order to meet the market demand, especially for derivated products, the Cilembu sweet potato may be obtained from other farmers whose lands have not been certified with IG, namely rancing sweet potato. With these demands, each system coordinates itself in the process towards the equilibrium point otherwise known as the law of requisite variety. PUCIMA led by KI modifies its marketing by wrapping the context of local stories with insertion of a scientific reason to boost the sale of Cilembu seeds, without losing the essence of the contents of the local stories.

In the second paragraph, the pattern of the information presented is $\mathrm{P}=(\mathrm{S} 3+\mathrm{S} 4)+\mathrm{K} 3+\mathrm{M} 3$. In this paragraph, $\mathrm{KI}$ incorporates story elements as much as 2 developed ideas, while knowledge and marketing elements as much as one idea.

(S4). "In the Cilembu village, sweet potatoes that have been harvested are not immediately sold, but ripened first by laying them under the house."

"Houses in the countryside in West Java, including in Cilembu, are always panggung (elevated), so that they have space under them. This space is used for ripening the Cilembu sweet potato, for a month.)

It is therefore important for marketing through information clutter when presenting the research result to customers (Doyle \& Tharme, 2011). Tobin and Snyman (2008, p 133) stated that since the beginning of humanity, storytelling already exist. At first, storytelling is used as a process of learning to think critically and understand also drafted a common experience (CarterBlack, 2007, p. 32). In this web-based cybernetic era, KI performs ethnostorytelling by utilizing information technology. The role that technology has played in the history of storytelling: in the past, technology was used as a tool to spread stories to a wider audience; presently, it is used as a tool that is an integrated part of the storytelling process and of the story itself (Czarnecki 2009, p. 5)

Folktales about the storage of sweet potatoes under the house and then meet with new knowledge which proves that the taste of Cilembu sweet potato is due to the fermentation reaction on potato starch.

(K3) "Even in Cilembu village, freshly harvested sweet potatoes are tasteless, because the starch has not been modified by enzymes, through fermentation into sugar.")

The scientific explanation also strengthens the notion that the local people's thinking of technology in ancient times have made progress in terms of container and content. With answers using scientific knowledge, the 
context is more convincing to customers that there is a process which makes sweet potatoes release liquid as sweet as honey. KI sees these opportunities as a form of creative thinking. About the need for variation, the idea to coordinate them has produced a basic draft. To change an object of local stories where there is interaction between the object and its environment will alter the object as desired. (Becker et al, 2006).

"I explored. Since I am motivated to write a blog, I want to tell a story, to tell a story to the reader. For accuracy, I asked parents here. I was looking for information up to my grandfather. Initially, I was recalling. So, there are some facts and some things which are questionable. Such as the saying "this potato is so sweet", the impact is that the potato becomes sweet. I mean to say the local story is true or not. Regarding the prince of Sumedang who visited and was served by the citizens, in my opinion it's a fact. There is photograph evidence of the past. Today, I do not know if they still exist or not. I have looked in the museum, I have traveled just because I want to know about the Cilembu sweet potato.")

KI shows a good behavior of information seeking, which is referring to the sources of primary information by visiting the museum and reading documentary evidence such as photographs. KI 2 considers the local story as not a fact. It is not scientific. Folktales are questionable. Nonetheless, storytelling is used in many different business disciplines, some of which are leadership, management, coaching, selling, education, and branding. (Bosworth \& Zoldan, 2012; Carr \& Ann, 2011, p.236; Sliverman, 2006).

Information pattern in the third paragraph, namely $\mathrm{P}=$ $\mathrm{S} 5+(\mathrm{K} 4+\mathrm{K} 5)+\mathrm{M} 4$. KI raises two developed ideas of the knowledge element. ("However, once harvested do not immediately put into oven, but ripened up first.) (K4). (Regions around Salatiga are suitable for the cultivation of Cilembu sweet potato, because the agroclimate is equal to the area of Sumedang, West Java.) (K5). James and Minnis (2004) added that storytelling facilitates knowledge sharing, guides decision-making and creates commitment to change.

The information pattern of the fourth paragraph is $\mathrm{P}=$ $(\mathrm{K} 6+\mathrm{K} 7)+\mathrm{M} 5$. The pattern of fifth paragraph, $\mathrm{P}=(\mathrm{K} 8$ $+\mathrm{K} 9)+(+\mathrm{M} 6 \mathrm{M} 7)$. The pattern of the sixth paragraph, $\mathrm{P}=(\mathrm{K} 10+\mathrm{K} 11)+(\mathrm{M} 8+\mathrm{M} 9)$. In these paragraphs, the story element does not exist. They still emphasize the elements of knowledge that explains the facts of the story and also element of marketing that uses the story as a scientific reason, rational and practical study. This broke the presumption that a story is the antithesis of scientific, objective or rational research practice (Florence, 2013; Ghoshal, 2011, p.4), that the use of stories lacks perception. ("Sweet potato is most suitable to be cultivated in the middle plains, with an altitude between 400 up to $800 \mathrm{~m}$ above sea surface such as Salatiga.") (K6). ("If it is cultivated in the lowlands ranging from $0 \mathrm{~m}$ to $200 \mathrm{~m}$, then in three months it should have already been harvested, so that the tubers are not attacked by the borers. On the other hand, if the sweet potato is grown on higher altitudes (above 1000 $\mathrm{m})$, it will not be attacked by borers, but it can harvested in up to a year.) (K7).

\section{DISCUSSION}

Storytelling offers various advantages. It facilitates engaging and interactive conversations, is intuitive, stimulates the brain and aids recall, is simplified, increases impact and facilitates understanding (Carr \& Ann, 2011, p.242; Davidson, 2011, p. 12-16; Deloitte, 2011; Few 2011, p.10; Kaidi, 2012, Maritz et al, 2014, p. 3)

1. The application of the model 15-Co for product marketing can be developed in other contexts, such as products and services that elevate local knowledge for sustainable community economic development.

2. Facilitation of training and workshops for SMEs in building cybernetics ethnostorytelling for local products is needed.

3. The mapping of information content in the form of a narrative that uses multimedia is needed.

\section{CONCLUDING REMARKS}

1. A story is a narrative information that in the era of modern cybernetics is no longer a container and content but also lead to the context.

2. A local story can become the people's choice in strengthening the resilience of the economy in various fields.

3. A local story can be an affirmation that educate, so that local people obtain economic literacy skills.

4. Economic literacy is simply interpreted as "reading to obtain financial gain," at least in microfinance. 
5. Etnostorytelling marketing for the distribution of Cilembu sweet potato seeds is wrapped using the principles of $15 \mathrm{C}$ and 6 pillars of successful storytelling.

6. The cybernetics model as a controlled system and cybernetics as an autonomous system both apply to ethnostorytelling marketing via multimedia, web, and blog

\section{ACKNOWLEDGEMENT}

Through this acknowledgement, we express our sincere gratitude to all those people who have been associated with this research project and have supported us and made it a worthwhile experience. We extend our thanks to the Cilembu Village community, and also Mr Firman and Mr Yusuf (CV PUCIMA) as the informants.

\section{REFERENCE}

Becker, et al., 2006, The History and Development of Cybernetics. The George Washington University.

Bosworth, M. \& Zoldan,B, 2012, What great salespeople do: The Science of selling through emotional connection and the power of story, Mc GrawHill Companies, Inc. Hoboken, NJ.

Carr, A.N. \& Ann,C., 2011, The use and abuse of storytelling in organizations', journal of Management Development 30 (3), pages 236245.

Carter-Black, 2007, Teaching Cultural Competence: An Innovative Strategy ground, page 32.

Czarnecki, K., 2009, storytelling in context. In digital storytelling in practice, Library Technology Reports, Chicago, IL. Pages 1-5.

Davison, L., 2011, As stimulating as black coffeecommunications that are hard to sleep after, paper presented at ESOMAR Annual Congress, Amsterdam, The Netherlands, September. pages. 12-16.

Deloitte, 2011, Tech Trends 2011 (electronic Version), viewed April 2016, from http://www.deloitte.com/us/2011techtrends\#dow nload

Doyle, A. \& Tharme, A., 2011, Do researchers understandvisual design?, viewed 12 August 2016, from http://www.researchlive.com/features/do-researchers-understandvisual-design?/4004766.article
Ethnojournalism.org, 2016, Multimedia Empowerment \& storytelling. Hosted by ibiblio.org

Few, S., 2011, The chartjunk debate. A close examination of recent findings', Visual Business Intelligence Newsletter April/May/June. Available from http://www.perceptualedge.com/articles/visual_b usiness intelligence/the chartjunk debate.pdf. page. 10

Florence, C., 2013, A matter od fact, not fiction, viewed February 2015, from http://www.researchlive.com/comment/a-matter-of-fact-notfiction/4009220.article.

Ghoshal, N.D., 2011, Storytelling:Co-create atale', admap, October, page.4.

James, C. and Minnis, W.c., 2004, Organizational storytelling: it makes sense', business horizons 47 (4), Pages 23-30.

http://dx.doi.org/10.1016/S0007-6813 (04)00045-X

Kaidi, Z., 2012, Data Visualization, viewed 12 August 2012 ,

from http://www.cs.uic.edu/ kzhao/papers/00_course_ Data_visualization.pdf

Maritz, V., Petzer, D.J. \& De Meyer, C., 2014, The use of storytelling in quantitative research reports: A marketing research firm perspective, Acta Commercii 14 (2), Art. \#48, 10 pages. http://dx.doi.org/10.4102/ac.v14i2.248

Saunders E.B.N, 2000, Generative Tools for CoDesign Retrieved from http://www.daimi.au.dk/ pkrogh/UX_kursus_aaa E09/Sanders\%20generative\%20tools.pdf

Silverman, LL., 2006, Wake me up when the data is over, John Wiley \& Sons, Inc., Hoboken, NJ.

Slikkerveer, L.J, 2005, The Rise of Ethnomedicine in Indonesia: Innovative Wisdom for The Advancement of the medical Social Sciences. Bandung: Unpad.

Tobin, P.K.J. \& Snyman, R., 2008, Once upon a time in Africa: A cas study of storytelling for knowledge sharing. Aslib Proceedings 60 (2). Pages.130-142. http://dx.doi.org/10.1108/00012530810862464 
Table 1. Cybernetics-Based Information Pattern (June, 2013; 01:38 WIB)

\begin{tabular}{|c|c|c|c|}
\hline \multicolumn{4}{|c|}{$\begin{array}{c}\text { Text Title in the Blog : } \\
\text { (Cilembu Sweet Potato Does Not Taste Sweet, WHY?) }\end{array}$} \\
\hline Prologue (P) & Percentage (\%) & Paragraph & Information Pattern \\
\hline (f) 1 & $4 \%$ & 1 & $\mathrm{P}=\mathrm{S} 1+(\mathrm{K} 1+\mathrm{K} 2)+(\mathrm{M} 1+\mathrm{M} 2)$ \\
\hline $\begin{array}{l}\text { Local Story } \\
\text { DHC (S) }\end{array}$ & \multirow[t]{2}{*}{$16 \%$} & 2 & $\mathrm{P}=(\mathrm{S} 3+\mathrm{S} 4)+\mathrm{K} 3+\mathrm{M} 3$ \\
\hline (f) 4 & & 3 & $\mathrm{P}=\mathrm{S} 5+(\mathrm{K} 4+\mathrm{K} 5)+\mathrm{M} 4$ \\
\hline $\begin{array}{c}\text { Scientific } \\
\text { Knowledge } \\
(\mathbf{K})\end{array}$ & \multirow[t]{2}{*}{$44 \%$} & 4 & $\mathrm{P}=(\mathrm{K} 6+\mathrm{K} 7)+\mathrm{M} 5$ \\
\hline (f) 11 & & 5 & $\mathrm{P}=(\mathrm{K} 8+\mathrm{K} 9)+(\mathrm{M} 6+\mathrm{M} 7)$ \\
\hline $\begin{array}{c}\text { Marketing } \\
\text { (M) }\end{array}$ & $36 \%$ & 6 & $\mathrm{P}=(\mathrm{K} 10+\mathrm{K} 11)+(\mathrm{M} 8+\mathrm{M} 9)$ \\
\hline
\end{tabular}

Source: Construction 